\title{
Social organization forms and institutional dynamics in the Tapajós-Arapiuns Reserve, state of Pará, Brasil
}

\author{
Modos de organização social e dinâmicas institucionais na \\ Reserva Extrativista Tapajós-Arapiuns, estado do Pará, \\ Brasil
}

Marcelo Moraes de Andrade ${ }^{a}$

Danielle Wagner Silva ${ }^{b}$

\begin{abstract}
aMaster in Rural Development, Universidade Federal do Rio Grande do Sul, Doctoral student in the Postgradute Program in Sociedade, Natureza e Desenvolvimento - PPGSND, Universidade Federal do Oeste do Pará - Ufopa, Santarém, PA, Brazil E-mail:mllblues@yahoo.com.br
\end{abstract}

${ }^{b}$ Ph.D in Rural Development, Universidade Federal do Rio Grande do Sul, Professor at the Universidade Federal do Oeste do Pará - Ufopa, Santarém, PA, Brazil E-mail: danicawagner@yahoo.com.br

Received: 01/12/2018

Accepted: 13/08/2019

ARTICLE - VARIA

\begin{abstract}
In this text, we will discuss the interdependence in processes that influence, directly or indirectly, the conditions of natural resources' appropriation and list social interactions that will draw corresponding institutional frameworks to which dwellers of the Tapajós-Arapiuns Extractive Reserve will affiliate. The research that supports this paper has a multidisciplinary character, relying on the usage of various tools for obtaining information. The analytical notion of institutions (formal and informal rules) has been used to reference the developed interpretations. The considered object of analysis reflects over practices in the dwellers' way of life, taking into account the alternatives of correlation between social organization and production practices. It is perceived that dwellers' social frameworks of organization were constructed, not only by traditional institutional apparatus, but also by using coordination instruments and land-use planning, to manage common resources. These principles create an institutional order based on a presumed rationality, with distinct unfoldings and social impacts.
\end{abstract}

Keywords: Institutions; Conservation Units; Institutional Apparatus; Social Changes.

\section{RESUMO}

Neste texto, discutimos a interdependência de processos que influem, direta ou indiretamente, nas condições de apropriação de recursos naturais e referenciam interações sociais que conformam correspondentes quadros institucionais a que se afiliam moradores da Reserva Extrativista TapajósArapiuns. A pesquisa que subsidia este texto tem caráter multidisciplinar, com utilização de diversas ferramentas para obtenção de informações. Utilizou-se a noção analítica de instituições (regras formais e informais) para referenciar as interpretações desenvolvidas. $O$ objeto de análise considerado incide sobre práticas referenciadoras dos modos de vida dos moradores, compreendidas pelas alternativas de correspondência entre organização social e práticas produtivas. Constata-se que os quadros sociais de organização dos moradores foram construídos não apenas por aparatos institucionais tradicionais, 
mas por instrumentos de coordenação e ordenamento territorial para gestão de recursos comuns, princípios que criam institucionalidade baseada em pressuposta racionalidade projetada, com distintos desdobramentos e impactos sociais.

Palavras-chave: Instituições; Unidades de Conservação; Aparatos Institucionais; Mudanças Sociais.

\section{INTRODUCTION}

Extractive Reserves correspond to a category of Conservation Unit - CU whose main legal frameworks are referenced in Law No. 9,985, July 18, 2000, which establishes the National System of Conservation Units - SNUC. As areas protected by public power, they constitute territories destined to the conservation of renewable natural resources and self-sustaining exploitation by extractive populations (ALLEGRETTI, 2008). The institutionalization of this category of CU appears "as a result of a political movement of the rubber tappers from Acre, in response to the attempt to expropriate the land and the process of overthrowing the forest" (CAVALCANTI, 2002, p.2).

The constitution of Extractive Reserves is convergent with the institutionalization of a set of norms referring to the use and appropriation of the territories that, supported by the SNUC, start to govern the social interactions between residents of the UC and the natural environment. The creation of these areas institutes a differentiated dynamic, since its management presupposes the insertion of resident social groups in the dynamics of the rational-legal apparatus of the State, the articulation with a wide network of actors formally constituted in instances of institutional representation (deliberative and / or Community council), formal instruments of territorial management (Management Plan, Management Agreement).

In the plan of this social construction, the projected and desired consent to norms and procedures also implies vigilance. Considering that, referentiated practices of the lifestyles of these social groups., linked to the use of forest resources, such as the constitution of clearings, the removal of wood for the construction of houses and the use of white straw on the cover, they start to depend on the authorization from the managing body of the $\mathrm{CU}$. For this reason, the constitution of these $\mathrm{CU}$ emphasizes its strongly normative character, to the point of claiming preconceived conceptions of a projected and supposedly effective order to legitimize paradigms of environmental conservation.

However, the relatively formal consent or agreement, so desired in the context of such construction, also implies the overcoming of many challenges, since then faced by the traditional populations residing in Extractive Reserves. One of these challenges, corroborating with Silva (2014, p.2), is "to decipher and learn how to move according to modern state rationality or be devoured by it".

The author criticizes, therefore, the state formalism that has been based on procedures of domination referrers of the relationship between public agents that manage CU and traditional populations, that is, by these terms recognized by previous installation in the corresponding spaces of framing. For him, this challenge is both an obstacle and a condition for overcoming obstacles that limit the presumed development of these populations. Referred to by Max Weber, Silva (2014), considers the State as the space of rational actions and the sphere of rational/legal domination, which is why he disputes this interdependent rationality in the face of the habitual practices of the resident populations in these CUs, traditionally linked to values and informal or consensual standards of conduct.

The different conditions for the constitution of the traditional populations of Amazon are highlighted in this context of interventions related to environmental policy, so at the same time, they give this category a peculiar mode of organization, whose knowledges, techniques, customs and values, articulate to the institutional dynamics that mark their way of life. Diegues (2000, p.22) points out some peculiarities of these groups when they recognize that their social differentiation was built on the reproduction of their "[...] way of life, in a kind of isolated way, based on modes of social cooperation and specific forms of relations with the nature, traditionally characterized by the sustained management of the environment".

Although, in order to achieve legitimacy, populations living in Extractive Reserves must base their actions on formal legal regulations derived from new intervening institutions. From the theoretical 
assumptions of North (1994), this context illustrates the relevance of the role of norms, formal and informal rules, values and beliefs in the organization of social ordering structures. Considering that their actions and practices are inherent in a "way of life based on informal community values passed on from generation to generation and crystallized through the ages" (SILVA, 2014, p.10), this differentiated reality nevertheless is constructed through strangeness of traditional populations in relation to the new ordering logic of daily life imposed by the CU condition.

Thus, in this text, we discuss the changes in social arrangements resulting from institutional changes affecting residents of the Anã and Boim communities located in the Tapajós-Arapiuns Extractive Reserve, from now on referred to as Resex. In this text, the analytical notion of institution adopted to refer to developed interpretations corresponds to the system of formal rules (legal apparatuses, laws, norms, etc.) and informal rules (sanctions, taboos, customs, traditions and codes of conduct).

The text is structured from four sections beyond this introduction and the final considerations. In the following section, we qualify methodological procedures and the referential empirical universe or the corresponding social situations; in sequence we briefly present the theoretical framework that has as an objective the discussion about the changes underway in CU. In the third section, subsidized by Little (2002), Barreto Filho (2006), Brasil (2007), Allegretti (2008) and Pureza, Pellin and Padua (2015), we deal with theoretical and normative definitions, specifically related to the traditional and Extractive Reserves. In the following section we present the results of the research, discussing ongoing social changes in the CU.

The discussions of this text are based on preliminary data referring to the doctoral research of the first author, under the guidance of Professor Delma Pessanha Neves, to whom we thank the reading of the first version of the text that was presented in oral communication format at the II International Seminar Latin America: Contemporary politics and conflicts, held in Belém, Pará, in the year 2017, which, afterwards, was revised and supplemented for submission to the journal.

\section{MATERIALS AND METHODS}

The field research that grounded this text was carried out with residents of Anã and Boim communities, located in Resex Tapajós-Arapiuns, in the cities of Santarém and Aveiro (Figure 1). According to the spatial organization of the State of Pará, Aveiro is located in the Southwest mesoregion and Santarém in the West. Part of the territory of Resex is located in the interflow of two important rivers of the region, Tapajós and Arapiuns, from there originating the name of the CU (BRASIL, 2014).

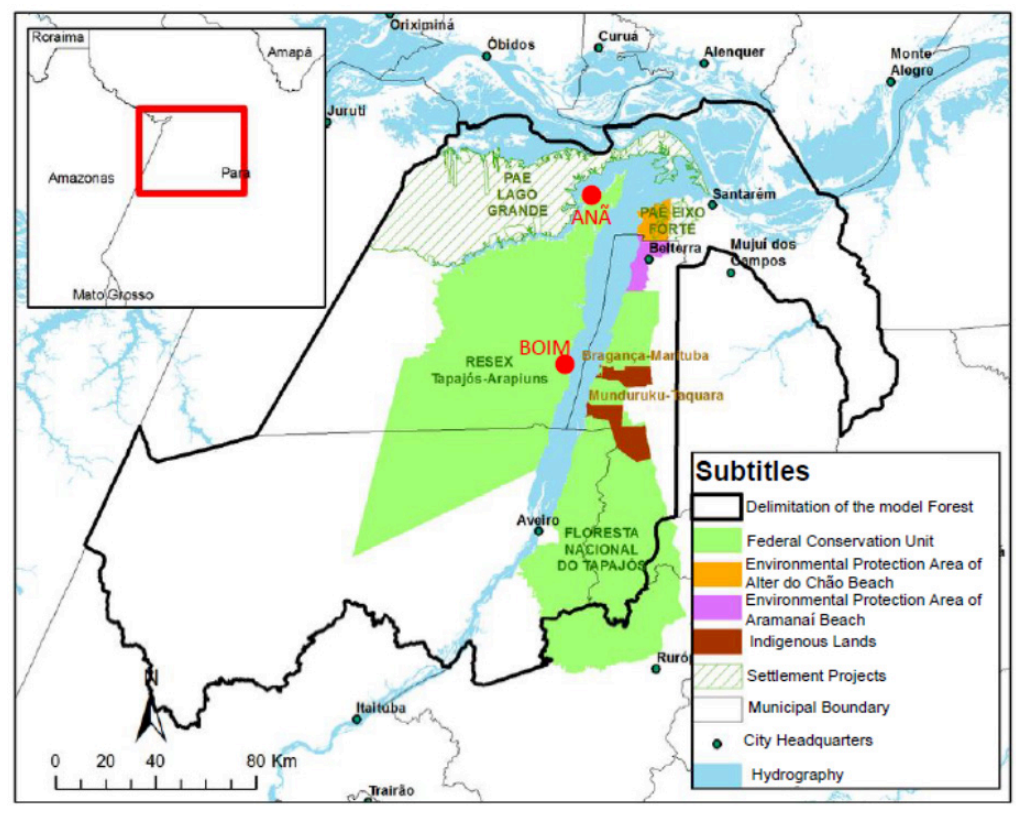

Figure 1 | Location of Anã and Boim in the regional context, highlighting the CU and municipalities.

Source: Adapted by the authors from the Serviço Florestal Brasileiro (SFB, 2017). 
Figure 1 above, illustrating the contextualisation of the spatial cut of the research site, exemplifies one of the geopolitical conceptions of the region. This representation of the region is part of the official management structure of the territory. Most of the riverside communities of Resex were formed from old villages made up of old Jesuit missions and places of remote indigenous villages (CEAPS - PROJETO SAÚDE ALEGRIA, 2012). According to data from the Management Plan (BRASIL, 2014) of the CU, in 2013, there were 75 communities distributed between the Tapajós and Arapiuns rivers, where around 3,466 families were living, which corresponded to approximately 27,027 community members. Boim community was founded in 1690 by Jesuits, had great importance for the region for having served as commercial warehouse for the 'drogas do sertão'. With a formation process very close to the one commonly found in riverside communities of the Amazon, the creation of Anã dates back to 1954. Each community has about 100 resident families.

Empirical data were collected from the following stages: i) participation and monitoring of the residents in institutional decision-making environments (deliberative and community councils), in meetings held between 2016 and 2019, in a total of 13 participations; ii) field incidences to conduct interviews and followup of routine family practices, nine (9) field trips were carried out, lasting from three (3) to six (6) days, during the years 2017 and 2018, in all, twelve (12) interviews were conducted with the help of a script.

In addition to the interviews, as a methodological instrument, participant observation was adopted. For Becker (1994, p. 58), participant observation is directly related to the concept of social system, "explaining specific social facts by explicit reference to their involvement in a complex of interconnectable variables that the observer constructs as a theoretical model of the organization".

\section{INSTITUTIONS AND INSTITUTIONALISM}

Given the breadth of meanings of the notion of institutions, it becomes necessary not only some qualifications, but also, to a certain extent, a position in the face of such significant debate aimed at assigning it precision and conceptual status. Thus, the study of institutions, also called 'institutionalism', in certain disciplinary fields reveals multiple meanings. In the field of economics, for example, the analytic current known as the New Institutional Economy - NIE was consolidated. This chain addresses issues related to the understanding of the role of institutions within the framework of various social structures, market and agent interaction (NORTH, 1994; PUTNAM, 2006; SANTOS, 2007).

In the NIE approach, institutions are human inventions designed to structure political, economic, and social interactions over time. According to North (1994), the institutions are formal rules (legal apparatus), informal (mental constructs) and mechanisms to guarantee compliance with these rules (NORTH, 1994).

For Bonfim (2007, p.20), "a basic distinction between informal and formal rules is that the first one don't need necessarily to be codified and protected in the legal system; they may in some cases only exist in people's minds". North (1994) recognizes that the major function of institutions is to ensure the regularity of human behavior while at the same time alerting to the need to identify how behaviors are altered as an expression of different institutional structures.

Dequech (2011), from the understanding that institutions are socially shared patterns of behavior, reflexively expresses this understanding. The first point to be considered, according to the author, is the inclusion of patterns, prescribed or described, which indicate what can and cannot be done (rules). His social construction refers to "[...] the contrast with genetic causes or another kind of natural cause" (DEQUECH, 2011, page 607).

In sociological institutionalism, besides formal and informal rules, institutions include "[...] the systems of symbols, cognitive schemas, and moral models that provide" patterns of meaning "that guide human action" (HALL; TAYLOR, 2003, p. 209). Studies' investments focus on the comprehension of the influence of institutions on the behavior modes of social actors as they provide cognitive structures, categories, and models. For this reason, these authors emphasize that the system of norms and modes of cognition are indispensable elements to the action, without which the interpretation of the world and the behavior of the actors would be impossible (HALL; TAYLOR, 2003). 
Douglas (1998), sharing a theoretical perspective similar to that assumed by Berger and Luckmann (1985), considers institutions as a framework of knowledge shared and transmitted as revenue, in which knowledge provides institutionally adequate rules of conduct. According to Douglas (1998, p. 60), "the more widely institutions hold expectations, the more they take control of uncertainties, with one more effect: behavior tends to conform to the institutional matrix".

Berger and Luckmann $(1985$, p. 79$)$ say that institutions originate from the typification that actors make of their habitual actions. The authors explain that these typifications, considered by them as reciprocal, constitute the stock of knowledge socially shared by individuals who, in the course of history, trigger and reproduce it. Saying that a segment of human activity was institutionalized is tantamount to claiming that it was subjected to social control. In this case, the need to develop new mechanisms of social control is only justified when the processes of institutionalization are not successful (BERGER; LUCKMANN, 1985). In this sense, as informal institutions reproduce these social controls, formal institutions, represented by legal normatization, come to play a secondary role as a control mechanism (BERGER and LUCKMANN, 1985).

If the conceptual commitment pointed out by several authors has been hitherto outlined, the distinctions demanded do not subordinate some agreements in relation to recognition that institutions are differently standardized according to contextual processes of construction and that they cannot be reduced to control because the definitions in search of consensual or tax agreements are a product of the cognitive condition of man that produces the social environment in which he reaches existence. Therefore, we assume a synthetic presentation of the notion of institutions for the purposes of this analysis, considering it sufficient to elucidate the pertinence of the term.

Théret (2003), in analytically constructing the distinction of institutionalism valued in Political Science, Economics and Sociology, affirms that "analyzed in common, they have coincident characteristics and mutual influences that lead to more convergent rather than divergent developments [...]". Thus, the notion of institutions that we will adopt is based on systematizations elaborated from the contribution of North (1994), Hall and Taylor (2003), Douglas (1998), Berger and Luckmann (1985).

\section{THE CREATION OF EXTRACTIVE RESERVES AND THE RECOGNITION OF TRADITIONAL POPULATIONS}

As Pureza, Pellin and Padua $(2015$, p. 130) point out, the concept of Resex was instituted in a troubled period when it comes to the land issue, especially in the North region of Brazil. The causes of this tension, although with much older roots, date back to the 1960's and 1970's. From the mid-twentieth century, the occupation of the Amazon territory was driven by several issues, in particular, migration resulting from the promotion of rubber extraction (FERREIRA, 2010).

In the field of conflicts, especially postulants of expectations of mitigation of conflicts and containment of the environmental impacts derived from the occupation of the Amazon territory, more expressive in the course of the 1990's, Federal and State governments invested in the creation of CU. At the end of that decade, the Extractive Reserve concept represented a special management paradigm, which encompassed a larger geographic area, a greater number of traditional communities, and problematized the possibility of development from the environmental sustainability bias.

According to Pureza, Pellin and Padua (2015, p. 132-133), from the perspective of extractivists, the Extractive Reserve form was valued as "an instrument of Agrarian Reform, from the moment they considered their implantation as a way of legitimizing possession and recognizing the rights to the land of those who took their livelihood from it and who had lived in it for many years". This way, the Extractive Reserves are areas of public domain, of which the traditional populations are users, under a concession contract of real right of use - CCDRU.

The notion of traditional populations results from a broad context of discussion, involving agents worldwide in the construction of ideas of environmental conservation, contemplating dialogues on 
the issue of human presence in protected areas (PUREZA; PELLIN; PADUA, 2015). The Convention on Biological Diversity - CBD, during ECO-92, is considered as the starting point for recognizing the potential of traditional populations to contribute to biodiversity conservation because of their knowledge and sustainable practices. Reaffirming the status achieved by the category, in the political-ideological field, in February 2007, through Decree No. 6,040, the Brazilian State instituted the National Policy for the Sustainable Development of Traditional Peoples and Communities.

The precise definition complexity of the traditional population category, when transmuted into an analytical concept, stems from the recognition that, in practice, this category can only be considered in its situational plurality (LITTLE, 2002). There are several notions that explain traditional populations, but in the analytical field there is agreement on the political recognition of residents of Extractive Reserves as traditional populations and convergence around the definition adopted by Barreto Filho (2006, p. 110): "the notion of 'traditional population' expresses a set of collective cultural values relating to the environment - perceptions, values and structures of meaning that guide and are at the origin of certain environmental policies".

As the author points out, the notion of traditional populations corresponds to a concept invented in the context of international conservationism, which carries with it, usually, criticisms as to its definition, since it is a category that encompasses notable situational diversity, thus operating in the homogenization of meanings, especially for the effects of the conflicts in the production and recognition of the rights acquired by the respective population segments. With this homogenizing definition, the category and the respective social groups so framed, are now recognized as subjects by the State.

In light of the foregoing, we prioritize the conditions in which the interactions between traditional institutions and populations residing in CU are interwoven, in particular, the institutional apparatuses, such as the set of norms established in the scope and in the constitution proper of Resex, consequently, respective modes of organization of the residents of the unit. Among the repertoire of institutional apparatus created by the creation of Resex, the Management Plan constitutes as one of the main intervention instruments for being a driver of the use of natural resources in the CU, built collectively foreseen in the SNUC. As a management tool, the Management Plan represents a form of formalization of institutions. Given its construction conditions, it brings together a hybrid where informal institutions can be institutionalized.

\section{BEYOND THE MANAGEMENT PLAN: INSTITUTIONS AND SOCIAL CHANGE PROCESSES IN PROGRESS IN THE TAPAJÓS-ARAPIUNS RESEX}

The creation of the Resex Tapajós-Arapiuns, as foreseen in the SNUC, demands the institutionalization of a set of formal norms that focus on the various interactions among residents, environmental legislation, natural environment and external agents. Therefore, although the Resex Management Plan was established in 2014, in 1999, one year after the creation of the CU, it was prepared by technicians of the Brazilian Institute of Environment and Renewable Natural Resources - IBAMA, in partnership with residents of Resex, the first normative instrument of the UC, the Plan of Use. This normative instrument had two functions: to regulate the use of natural resources and; it was a condition for the signing of the Concession Contract of Real Right of Use - CCDRU, which regulates the land tenure of the residents.

In September 2012, ICMBio published the Normative Instruction No. 29, which governs the guidelines for the elaboration of a Management Agreement in CU of sustainable use, which includes Extractive Reserves and Sustainable Development Reserves - SDR. Thus, by means of this Normative Instruction, the Resex Utilization Plan became known as the Management Agreement, however, the rules previously established were maintained.

In 2008 the preparation of the Resex Management Plan was started, approved and published in 2014, incorporating the Management Agreement. The Plan registers 51 norms distributed in five groups; of these, the group with the highest number of norms is the one that deals with the "land use and forest for extractivism", with 25 rules. 
The Management Plan is a technical document, its content, besides presenting a series of information about Resex, proposes rules for management (established in the Management Agreement, in common agreement between residents and managers of the State) and actions that aim at the economic and social development of communities.

This document was elaborated by various entities and government agencies, especially the managing body, the Chico Mendes Institute for Biodiversity Conservation - ICMBio and the Organization of Associations of the Tapajós-Arapiuns -Tapajoara Extractive Reserve, representative of all residents of the $\mathrm{CU}$ and concessionaire of the area.

Considering this normative scenario, we'll discuss some changes in progress regarding the social organization of the residents of Anã and Boim communities in relation to conditions in which institutional apparatuses, as formal-rule-setters, in contrast, are related to the paradigma considered traditional or customary of use of natural resources, once based on informal rules.

\subsection{REARRANGEMENTS OF DELEGATED REPRESENTATION}

The social impact of Resex's creation was reflected in the ways of social representation of the residents, since it generated the need for collective organization structured according to the requirements of the field of mediation, usually through associations. The formalization of social organization is institutionalized by the agents of the State as a more articulated form for territorial management, being configured as a regulatory instrument that composes the institutional environment and governance structures. North (1994) emphasizes that the institutional environment is considered the context in which the guiding principles of norms that define the rules of the game are defined.

It is important to consider that organizational experiences are inherent parts of the organization of communities in the region; however, after the creation of Resex, the number of community and intercommunity associations increased significantly, to ensure representation and promotion of innovative or standardized participatory management. The Resex deliberative council, the main decision-making body, consists of 50 seats, of which 29 are for community and inter-community associations belonging to the CU.

In the prior context to the creation of Resex, in Anã and Boim communities, there were, respectively, two and one association. These associations were structured according to informal organization models, without registration in the National Registry of Legal Entities - CNPJ, absence of statute and without accountability. The process of selecting the managing members of the associations took place through agreements in assemblies, that is, according to the willingness of the group members to accept or not. The political organization was relatively restricted to the residents recognized for belonging to the communities.

In the current context, there are seven associations in Anã community, four being regularized with the competent body. In this community, this form of organization is due to the demand for competition to access resources to the implementation of income generation and food production projects. The associations receive administrative and financial advice from non-governmental organizations - NGOs. Boim has three associations, two with CNPJ. The increase in the number of associations in Boim, according to interviewees, is due to personal dissension among residents.

The models of formal associations, whose actions are referenced to rules in the social status, have consecrated an organizational structure of management (Administrative Council, Board of Directors and Fiscal Council), with the choice of managers through elections with mandates of temporality previously limited. The associations are the target of many governmental policies as a way of meeting social demands, which favors the development - or even imposition - of this type of organization. This fact has consequences, since the associations are responsible for the structures of governance instituted and legitimized by the State or increasingly defining power relations in the communities and, in these terms, also of conflicts not always resolved by the recommended consensuality. 
The associations conform arenas of clashes, corresponding to the construction of spaces of mediation of conflicts. The search for consensus on social issues presupposes the negotiation of conflicting interests made explicit in spaces of negotiation and deposition of power. As kinship relationships are structuring of community life, they are reflected in the processes of choosing members of associations, councils and community leaders, differential positions that give the occupant a certain status in this field of relations.

If, on the one hand, the associations are widespread because they constitute possibilities for dialogues between community members and institutional agents, on the other hand, they can be destructuring of traditional arrangements. The organizational pattern established by the formal associations, which allow dialogues with the State through several representatives, imposes a reordering of the leaders' way of acting, since it is their function to transit in referenced spaces or members of the State.

This fact denotes that the political organization is constituted in a network, in relational contexts of the social agents. Since the forms of mobilization prior to the creation of Resex were based on informal models, from the reading of North (1994), it can be considered that, by increasing the number and range of action of the associations, they represent a new institutional structure.

\subsection{INSTITUTIONAL CHANGES IN SOCIOPRODUCTIVE PATTERNS AND IN THE WORK PROCESSES}

Many inhabitants of Boim and Anã communities articulate their life history associated with extractivism, wether it is rubber latex (Hevea Brasiliensis), chestnut (Bertholletia Excelsa), sucuba (Himatanthus sucuuba), jutaí-cica (Muirapixuna Caesalpiniaceae), andiroba (Carapa guianensis Aubl), or other natural resources. In both communities, most of the older residents were rubber tappers or they are children of rubber tappers. Some still maintain rubber trees in the expectation of valorization of the product in the market, but also as a symbol of an era where everyday life was organized around the extraction of rubber.

For a long time, the extraction of latex and the production of cassava flour, were the main economic activities in the area now regulated as Resex and also the ones that most demanded labor. By the fact that these activities correspond to a specific historical context and are built around the association of objectives that articulate social organization to world views, ways of projection of organizational structures and individual postures, fundamental factors in the configuration of this social mediation (COSTA, 2009) of community management, both the extraction of the seringa and the manufacture of cassava flour constituted forms of institutions. Its construction, traditionally recognized, happened through a set of rules that function as filters between individuals and the stock of natural resources, physical capital, human capital, technology and knowledge, as conceived by North (1994) and Costa (2009).

However, due to the reduction in the demand for these products, the number of people engaged in these activities is decreasing. The production of cassava flour, which once demanded the use of family labor, has gradually lost importance, both as an agricultural activity and an activity that allocates family labor.

Moreover, the shifting cultivation of cutting and burning in communities, historically practiced by Amazon peoples, after the creation of Resex has been regulated by the rules established by the Management Plan. As the productive potential of the region's soils is short-lived, up to three years, at the end of this period, farmers began a new productive cycle with cutting and burning of a new open area in the forest. These areas were previously defined by means of community agreements. The areas chosen for production were those with the highest biomass potential, in other words, primary forest areas.

Currently, the opening of areas for cultivation in Resex is conditioned to the previous license application issued by ICMBio, which indicates the size and location of the area to be felled. The areas were established according to the zoning included in the Management Plan. The areas destined to the use of the population are secondary forest and fallow areas (capoeiras). The opening of areas for cultivation without authorization and/or outside the indicated place subject the resident to fines. This new context of activity management, based on conservation and external control ideals, re-signifies the relationship of the residents with the territory, generating a sense of loss of autonomy over the decisions about their alleged activities. 
Activities such as hunting and fishing have also been and are important practices that define the social identity of the peoples of Resex. These practices are activities learned from parents, who also transmit a system of value built and institutionalized over the years, marking the institutional dynamics, lifestyles of these individuals and respect for the preservation of species and social reproduction of the group. In this sense, these activities are influenced by socio-cultural values, namely, historical and symbolic, which tend to be in conflict with the principles of territorial interventions that refer to the access and use of natural resources.

With the collapse of the extractive economy and the gradual reduction of cultivated area, Boim and Anã communities have sought employment opportunities in urban centers. The integration of community members into the circuit of wage labor demands in the communities has been through the linkage to minimum public services, such as public education network and health posts. But it is also possible to find residents who are acting as permanent employees outside Resex. In each family situation the man or woman lives in the city of Santarém to work, while the other member of the couple stays in the community taking care of the house, the children and, in some cases, the plantation. With regard to physical presence, the family expresses the full recomposition by the return of the resident in the city to the community on weekends.

Regarding to collective work processes, the community members demonstrate regret with the growing disuse of the organization for cooperative work in the preparation of the field for the cultivation of cassava. The task forces, locally called puxiruns, were once an important practice based on the logic of the exchange of the day of work and mutual aid, but their meanings were also related to the sociability of the families involved, social dynamics based on interdependence. The puxiruns involves men, women, young people and even children, aggregation that requires a lot of organization to feed the workers and carry out the expected task.

The decline of the puxirum is associated with the extension of the bond of the farmers to the mercantile economy through the circulation in the communities of goods and products as commodities, as well as the replacement of agricultural labor by wage labor. In addition, there were changes in the form of payment of working days: people started asking for payment, instead of changing working days.

The monetarization of reward for working days, associated with the decline of cultivated areas, is institutionalized in relations between redundant neighbors of performance depression of another practice regarded as standard/standard habit. In this way, the institutional arrangement configured by the puxirum - once responsible for the regularity of mutual aid, reciprocity, has been weakened, evidencing institutional changes in the organization of work processes and reverberating in the social life as a whole. Consequently and/or in parallel, there was also a decrease in the number of plantations, even in the face of the restrictions imposed by the corresponding implantation and the alternative of buying many of the products previously cultivated for self-consumption or productive self-consumption.

However, recent experiences have arisen especially with the introduction of projects to generate sources of income in Anã community, such as fish production, fish food production, melipona honey extractivism, community based tourism, and hen breeding, have been contributing to changes in working relationships in the community. It should be emphasized, then, that these activities are complementary to wage labor, favoring productive and mercantile processes that allow families to reach their projected standards of consumption alternatives and financial income composition.

Bonfim (2007) points out that, from the institutionalist point of view, institutions are created to serve the specific function. In this sense, they are expressions of contextual dynamics, with specific social and economic characteristics. Considering that the institutions' major function is to ensure the regularity of human behavior, North (1994) warns of the need to identify how behaviors are altered by different institutional structures.

In this sense, it can be observed that the combination of several productive activities associated with changes in work processes is also referenced by different institutional structures in other social spaces (wage labor in urban centers), to which the residents of Resex are affiliated in the search for sources of income, minimizing the economic dependence of the natural resources. 
Added to these factors is the significant number of families with access to public income transfer programs, the most representative being Bolsa Família, retirement, insurance closures, maternity pay and unemployment insurance, which contribute to increased circulation of money in Resex.

We emphasize that, in addition to the institutional apparatuses outlined by the creation of Resex, the residents are also subject to influences related to processes of social changes of broader spectra, such as field-city migration. Such processes, objectified in the daily practices of the residents, promote changes in their social relations, consequently, in their institutions.

\section{FINAL CONSIDERATIONS}

In this text we analyze changes in the social arrangements resulting from institutional changes affecting residents of Anã and Boim communities, located in the Tapajós-Arapiuns Resex. It was found that, along with the set of standards instituted by the creation of Resex, many changes that have taken place or are under way, although they do not constitute changes directly related to the creation of Resex, were considered important here to understand these changes. In this way, we use the concept of institutions, understood as the rules of social play, of norms and values that guide day-to-day conduct, as a significant element in the analysis as they regulate the interactions of the residents of the CU.

Throughout the formation of the territory, the social frameworks of the residents of Anã and Boim communities were built by traditional and non-traditional institutional apparatuses. But also by external institutions that are instrumental in coordinating and territorial planning for the management of common resources, principles that create institutions based on presupposed projected rationality, with different consequences and social impacts. Besides these institutions, elements of modern life greater contact of residents of Resex with urban means, which allow assimilation of certain customs and values, such as the aspiration of consumer goods and industrialized products, change in the local economic structure through the insertion of posts of wage labor inside and outside the communities, a certain democratization of money - are deployment related to a broad process of economic and social development of the country, but that are affecting the daily lives of the populations of Resex.

In this sense, based on the analyzes previously presented, it can be affirmed that there are occurring referring resignifications of the practices of organization of the residents of the communities Boim and Anã, emphasizing that transformations in institutional structures are responsible for creating differentiated logics and rationalities. The changes and phenomena that are present in the daily lives of the Resex families express the coevolution of mutable and relatively interchangeable universes, built in environments of transformation, conflict and disputes.

Indeed, families are restructuring their modes of organization after the institutionalization of a set of formal rules as a result of the creation of Resex and a set of informal rules based, but mainly legitimized, in the constructed and reaffirmed tradition, construct relatively neutralized parameters for the expression of contradictions and oppositions. The supposedly peaceful reference to tradition is a qualification of senses re-created for opposing and questioning the legitimacy of intervention, legitimated by more or less effective forms of negotiation.

However, in the very process of rationalized conception of the residents, in this new context, an interposition took place, even because not all of them acted decisively in the demand for the constitution of Resex and of so many new associative forms. Being a differentiated cognitive universe with which the residents must coexist, they end up by reaffirming, to a higher or lower intensity, the externality character (or "thing to be object of reflection") to be questioned.

At the same time that the supposed and contextually reaffirmed tradition is questioned or denatured, this very one and the world of the assigned external agents are object of reflection and criticism, not always being maintained in this plan, or being constructed by the search of consensus among residentes. These when talking to researchers, visitors or commenting on each other on the yards that link homes and plantations, in the midst of critical whispers about selective non-legitimized intervention practices, it is to be expected or it is possible to be counted, that they may reflect the production of 
other referential meanings for the interaction among the agents. Thus, concluding, we highlight the important cognitive dimension valued by the authors mentioned by us, as inherent in the practices of defining norms, values and systems of formal or informal rules.

\section{REFERENCES}

ALLEGRETTI, M. H. A construção social de políticas públicas: Chico Mendes e o movimento dos seringueiros. Desenvolvimento e Meio Ambiente, n. 18, p. 39-59, jul./dez. 2008. Editora UFPR. Disponível em: <https:// revistas.ufpr.br/made/article/view/13423>. Acesso em: 09 jul. 2018.

BARRETO FILHO, H. T. Populações Tradicionais: introdução à crítica da ecologia política de uma noção. In: ADAMS, C.; MURRIETA, R.; NEVES, W. (Org.). Sociedades Caboclas Amazônicas: modernidade e invisibilidade. São Paulo: Annablume; Fapesp, 2006, p. 109-143.

BECKER, H. Métodos de pesquisa em ciências sociais. 2. ed. São Paulo: Hucitec, 1994.

BERGER, P. L.; LUCKMANN, T. A construção social da realidade: tratado de sociologia do conhecimento. Tradução: Floriano de Souza Fernandes. Petrópolis, RJ: Vozes, 1985. 248 p.

BONFIM, F. C. R. Governança ambiental e unidades de conservação do meio ambiente: uma abordagem institucionalista. 2007. 200 f. Dissertação (Mestrado em Economia de Empresas) - Escola de Economia, Fundação Getúlio Vargas. Disponível em: <http://bibliotecadigital.fgv.br/dspace/handle/10438/1832>. Acesso em: 3 nov. 2016.

BRASIL. Ministério do Meio Ambiente. Instituto Chico Mendes de Conservação da Biodiversidade. Portaria no 124. Plano de Manejo Reserva Extrativista Tapajós-Arapiuns, v. 1 - Diagnóstico. 2014. Disponível em: <http:// www.icmbio.gov.br/portal/biodiversidade/unidades-de-conservacao/biomas-brasileiros/amazonia/unidadesde-conservacao-amazonia/2045>. Acesso em: 29 dez. 2014.

CAVALCANTI, F. C. S. A política ambiental na Amazônia: um estudo sobre as Reservas Extrativistas. 2002. 223 f. Tese (Doutorado em Ciências Econômicas) - Universidade Estadual de Campinas, Instituto de Economia, 2002. Disponível em: <http://repositorio.unicamp.br/bitstream/REPOSIP/286314/1/Cavalcanti_FranciscoCarlosdaSilveira_D.pdf>. Acesso em: 19 jun. 2018.

CENTRO DE ESTUDOS AVANÇADOS EM PROMOÇÃO SOCIAL E AMBIENTAL - Projeto Saúde Alegria. Prazer em conhecer - Anã - Rio Arapiuns. 2012. Disponível em: <www.saudeealegria.org.br>. Acesso em: 27 jan. 2016.

CONCEIÇÃO, O. A. C. A contribuição das abordagens institucionalistas para a constituição de uma teoria econômica das instituições. Ensaios FEE, Porto Alegre, v. 23, n. 1, p. 77-106, 2002. Disponível em: <http://revistas.fee.tche. br/index.php/ensaios/article/view/2029>. Acesso em: 12 mai. 2015.

COSTA, F. A. Desenvolvimento agrário sustentável na Amazônia: trajetórias tecnológicas, estrutura fundiária e institucionalidade. In: BECKER, B. K.; COSTA, F. de A.; COSTA, W. M. da. (Org.). Um projeto para a Amazônia no Século 21: desafios e contribuições. Brasília: Centro de Gestão e Estudos Estratégicos, 2009, v. 1, p. 215-300. Disponível em: <http://www.scielo.br/scielo.php?script=sci_arttext\&pid=S0104-06182012000200002>. Acesso em: 19 dez. 2014.

DEQUECH, D. Instituições e a relação entre economia e sociologia. Estudos Econômicos (USP. Impresso), v. 41, p. 599-619, 2011. Disponível em: <http://www.scielo.br/pdf/ee/v41n3/a05v41n3.pdf>. Acesso em: 04 mar. 2017.

IEGUES, A. C. S. Os saberes tradicionais e a biodiversidade no Brasil. (Org.) DIEGUES, A. C. S. et. al. São Paulo: Ministério do Meio Ambiente/Núcleo de Pesquisas sobre Populações Humanas em Áreas Úmidas, 2000. 211 p.

DOUGLAS, M. Como as instituições pensam. Tradução: Carlos Eugênio Marcondes de Moura. São Paulo: Editora da Universidade de São Paulo, 1998. 161 p.

FERREIRA, F. S. S. Políticas públicas de ordenamento territorial no Baixo Amazonas (PA): uma análise a partir das políticas e programas dos governos federal e estadual na área de influência da rodovia BR-163 (Cuiabá-Santarém). 2010. 283 f. Dissertação (Mestrado em Ciências Sociais) - Programa de Pós-Graduação em Ciências Sociais em 
Desenvolvimento, Agricultura e Sociedade, Universidade Federal Rural do Rio de Janeiro. Disponível em: <http:// campohoje.net.br/sites/default/files/acervo/dissertacao_fernanda_ferreira.PDF>. Acesso em: 17 dez. 2014.

HALL, P. A.; TAYLOR, R. C. R. As três versões do neoinstitucionalismo. Lua Nova [on-line]. 2003, n. 58, p. $193-223$. ISSN 0102-6445. Disponível em: <http://dx.doi.org/10.1590/S0102-64452003000100010>. Acesso em: 13 mar. 2017.

LITTLE, P. E. Etnodesenvolvimento local: autonomia cultural na era do neoliberalismo global. Tellus (UCDB), Campo Grande, v. 2, n. 3, p. 33-52, 2002. Disponível em: <http://www.tellus.ucdb.br/index.php/tellus/article/ view/23/32>. Acesso em: 23 fev. 2017.

NORTH, D. Custos de transação, instituições e desempenho econômico. 3. ed. Rio de Janeiro: Instituto Liberal, 1994. $38 \mathrm{p}$.

PUREZA, F.; PELLIN, A.; PADUA, C. Unidades de Conservação. São Paulo: Matrix, 2015. 240 p.

PUTNAM, R. D. Comunidade e democracia: a experiência da Itália moderna. Rio de Janeiro: FGV, 2006.

SANTOS, S. R. S. Nova Economia Institucional. In: SEMINÁRIO TEMÁTICO CENTRALIDADE E FRONTEIRAS DAS EMPRESAS NO SÉCULO XXI, I, 2007, São Carlos. Anais... Disponível em: <https://www.google. com.br/url?sa=t\&rct=j\&q=\&esrc=s\&source=web\&cd=1\&cad=rja\&ved=0CCsQFjAA\&url=http $3 A \quad 2 \mathrm{~F} \quad 2 \mathrm{Fd}$. yimg.com 2Fkq 2Fgroups 2F16643321 2F2709464592Fname2FA2Bnova2Beconomia2Binstitucional. pdf\&ei=8dVvUreQBs2NkAeUjICQAg\&usg=AFQjCNFurTfUgAr282WtUzILMStzbIV1vQ\&bvm=bv.55123115d. eW0>. Acesso em: 29 dez. 2014.

SILVA, J. B. População tradicional residente em Reservas Extrativistas na Amazônia Brasileira. In: XIV SIMPÓSIO DE GEOGRAFIA DA UDESC, 2014, Florianópolis: Programa de Pós-Graduação em Planejamento e Governança Pública - PPGPGP, 2014. v. 2. p. 1-15. Disponível em: <http://www.eventos.ct.utfpr.edu.br/anais/snpd/pdf/ snpd2014/810.pdf>. Acesso em: 20 mar. 2017.

THÉRET, B. As instituições entre as estruturas e as ações. Lua Nova [on-line]. 2003, n. 58, p. 225-254. ISSN 01026445. Disponível em: <http://dx.doi.org/10.1590/S0102-64452003000100011>. Acesso em: 16 mar. 2017. 